\title{
DNA Cross-Link Repair 1A Protein
}

National Cancer Institute

\section{Source}

National Cancer Institute. DNA Cross-Link Repair 1A Protein. NCI Thesaurus. Code C106144.

DNA cross-link repair 1A protein (1040 aa, $116 \mathrm{kDa}$ ) is encoded by the human DCLRE1A gene. This protein plays a role in both the mitotic spindle cell cycle checkpoint and DNA repair. 